\title{
The Evaluation of Pediatric HIV Care in Congo
}

\author{
J. Kambourou ${ }^{1,2}{ }^{*}$, L. N. Motoula Latou ${ }^{1}$, Moyen Engoba',2, A. R. Okoko', H. L. Atanda ${ }^{3}$, G. Moyen ${ }^{1,2}$ \\ ${ }^{1}$ Pediatric Intensive Care Service, University Center Hospital (UCH) of Brazzaville, Brazzaville, Congo \\ ${ }^{2}$ Faculty of Health Sciences, Université Marien-Ngouabi, Brazzaville, Congo \\ ${ }^{3}$ Medico Social Centre Total EP, Pointe-Noire, Congo \\ Email: ^judycokam@yahoo.fr
}

How to cite this paper: Kambourou, J., Motoula Latou, L.N., Engoba, M., Okoko, A.R., Atanda, H.L. and Moyen, G. (2017) The Evaluation of Pediatric HIV Care in Congo. Open Journal of Pediatrics, 7, 197-204. https://doi.org/10.4236/ojped.2017.73023

Received: August 11, 2017

Accepted: September 18, 2017

Published: September 21, 2017

Copyright (c) 2017 by authors and Scientific Research Publishing Inc. This work is licensed under the Creative Commons Attribution International License (CC BY 4.0).

http://creativecommons.org/licenses/by/4.0/

(c) †) Open Access

\begin{abstract}
Pediatric AIDS is still a public health issue. In order to improve the care of children living with HIV, a study was carried out between January and December 2014, that is in 12 months at University Center Hospital (UCH) of Brazzaville, in the two Ambulant Treatment Centers (ATCs) of Brazzaville and Pointe-Noire, In three general hospitals and seven base hospitals. Heads of centers and follow-up files of children aged 0 to 15 constituted the target population. The study variables concern the provision of care, the organization of structures and personnel, and data management. Thirteen health facilities, 13 heads of centers and 520 medical files were selected. HIV care was effective in nine out of eleven departments, only the two CTAs offered the entire package of activities. The diagnosis was made in WHO stage 3 in 433 cases (83.3\%), the pre-therapeutic assessment in 246 cases (47.2\%); Psychological care in 84 cases $(16.1 \%)$ whose $80(95.2 \%)$ in the ACT, nutritional management in 4 cases $(0.7 \%)$. Nine out of 13 centers did not have computer tools or materials for patient information and education; No center had sufficient staff. The dispensation of Anti-retroviral drugs (ARDs) is not based on any standard and the safety conditions of the laboratory providers are not guaranteed. The importance of the observed dysfunction makes it necessary to improve the general conditions of care.
\end{abstract}

\section{Keywords}

Evaluation, Pediatric HIV/AIDS, Care, Congo

\section{Introduction}

The HIV/AIDS pandemic, a social problem, is still one of the major causes of morbidity and mortality in the world. According to UNAIDS, 36.9 million people are living with HIV, including 2.6 million children [1]. Sub-Saharan 
Africa is the most affected continent with 25.8 million, (70\%) of people infected. Paradoxically, only $37 \%$ of these patients receive antiretroviral therapy [2]. Africa alone includes, $87 \%$ of children living with HIV and $90 \%$ of infant deaths are related to it [1].

In Congo, where anti-retroviral therapy is free, out of 10,708 children infected, only 1452 have access to a therapeutic treatment, that is, $13.5 \%$ [3].

In order to improve the care of children living with HIV, the objectives of this work are to assess the quality of care provided to children treated with antiretroviral, the organization, operation and management of Care centers, as well as to identify the factors that influence follow-up.

\section{Patients and Methods}

A cross-sectional descriptive and analytical study was carried out between January and December 2014, that is to say in 12 months in the sanitary formations responsible for the pediatric care of the HIV in the Republic of Congo.

The choice of these centers was guided by the health overview of each department, taking into account the type of center, the number of patients per center and the availability of the heads of centers.

A total of 13 health facilities, 13 heads of centers and 520 cases of children living with HIV were investigated. Two ambulant treatment centers (ATC) for HIV (Brazzaville and Pointe-Noire), Brazzaville University Hospital, three General Hospitals and seven basic hospitals. These centers accounted for virtually all the departments in the Congo, with the exception of two centers that did not have a pediatric HIV care center at the time of the survey.

The number of files of HIV-positive children was determined with the formula

$$
\frac{(1.96)^{2} \times p(1-p)}{(\text { set margin of error })^{2}}
$$

where $p$ is the report of the number of expanding children of HIV of every department on the total of departments. The margin of error was fixed to $5 \%$.

The target population consisted of heads of centers of pediatric HIV care and records of children aged 0 to 15 years followed in the selected centers.

To carry out the study, two data sheets for the collection of data were developed and completed by the same investigators. The first was for the collection of the information contained in the patient follow-up files and the second for the heads of the center.

Investigators were previously trained in investigative techniques, which consisted of visiting the health facilities, interviewing the heads of the centers, and counting the follow-up files. The study variables were:

Those related to the provision of care, referring to the package of activities established by WHO: screening (date, place and method of diagnosis), counseling, clinical monitoring (nutritional status, statural growth, disease classification), biological rate, (CD4 rate, viral load, transaminases, creatinine, glycaemia, lipid 
and lipase), support for adherence to the treatment, psychological and nutritional care, management and dispensing of medicines, Home visits, search for the lost cases.

Those regarding the organization of structures: the existence of a consultation room, a pharmacy, a laboratory and a radiology; as well as the equipment of the rooms;

Those concerning the organization of personnel: the composition of the medical and paramedical team, the qualification of doctors, supervisors, pharmacists and laboratory technicians.

Those related to data management: collection and storage media (follow-up files, registers, summary sheets, computer tool), completeness and relevance of the information collected (identity, clinical and biological monitoring, Therapeutic aspects: date of inclusion, therapeutic line, Cotrimoxazole prophylaxis, management of opportunistic infections, management of adverse effects, psychological and nutritional management, evolution under treatment).

Data capture, processing and analysis were performed using CS Pro (Census Survey Processing), Microsoft Excel and SPSS (Statistical Package for Social Sciences) software.

\section{Legal aspects:}

Our study received the favorable opinion (notice) of the Ethics Committee institutional of the Faculty of Science of the health of the university Marien NGOUABI and the authorization of the national Program of fight (wrestling) against the HIV/AIDS.

\section{Results}

- Care offers

- Activity Package

The activity package was evaluated on the basis of ten parameters (Table 1).

Table 1. Activities according to the type of health training.

\begin{tabular}{cccc}
\hline & PLHIV care center & & \\
\hline Activities & Reference hospitals & Base hospitals & CTA \\
\hline Screening & Yes & Yes & Yes \\
Counselling & Yes & Yes & Yes \\
Clinical monitoring & Yes & Yes & Yes \\
Biological surveillance & Yes & Yes & Yes \\
Medicament management & Yes & Yes & Yes \\
Treatment observation support & No & No & No \\
Psychological care & No & No & No \\
Food care & No & No & No \\
Home visits & No & No & No \\
Search for lost & No & No & No \\
Total & 5 & 5 & 10 \\
\hline
\end{tabular}


- Activities evaluation

Infection diagnosis

388 cases attest the information regarding diagnosis (74.6\%). We used Serology method on 305 cases $(90.3 \%)$ and the polymerase reaction chain (PCR) with 38 cases $(9.7 \%)$.

- Clinical surveillance

Clinical follow up data (nutritional state, stature ponderable growth, search for opportunist infections) were reported on 266 cases among which 31 (11.6\%) were monthly based and $161(60.5 \%)$ were quarterly. During the initial consultation, the classification was made on 264 cases (50.7\%) among which $162(31.1 \%)$ based on CDC and 102 (19.6\%) according to WHO.

Opportunistic infections were found in 157 cases $(30.2 \%)$. It was the case of pulmonary tuberculosis among 60 cases (38.2\%), digestive candida among 49 cases $(31.9 \%)$, bacterial pneumonitis with unspecified bacteria among 41 cases (26.1\%) and one suppurated otitis among 7 cases (4.5\%).

- Biological supervision

The pre-therapeutic checkup was found in 246 cases (47.2\%), Figure 1.

- Biological follow up

The quarterly biological follow up (CBC, transaminase, creatinine, glycaemia, lipemia, lipasemia) reported in 168 cases (32.3\%) was incomplete in all cases.

- Nutritional and psychological care

The psychological care support was carried out on 48 cases (16.1\%) among which 80 in ATC (95.2\%) and 4 (4.8\%) in the other centers.

The nutritional support concerns 4 cases $(0.7 \%)$ at ATC in Pointe Noire.

The therapeutic line was indicated in 412 cases (79.2\%). Zidovudine-lamivudine-nevirapine label was used among 412 cases: 223 cases (54.1\%) and stavidin-lamivudin-nevirapin; 198 cases (45.9\%).

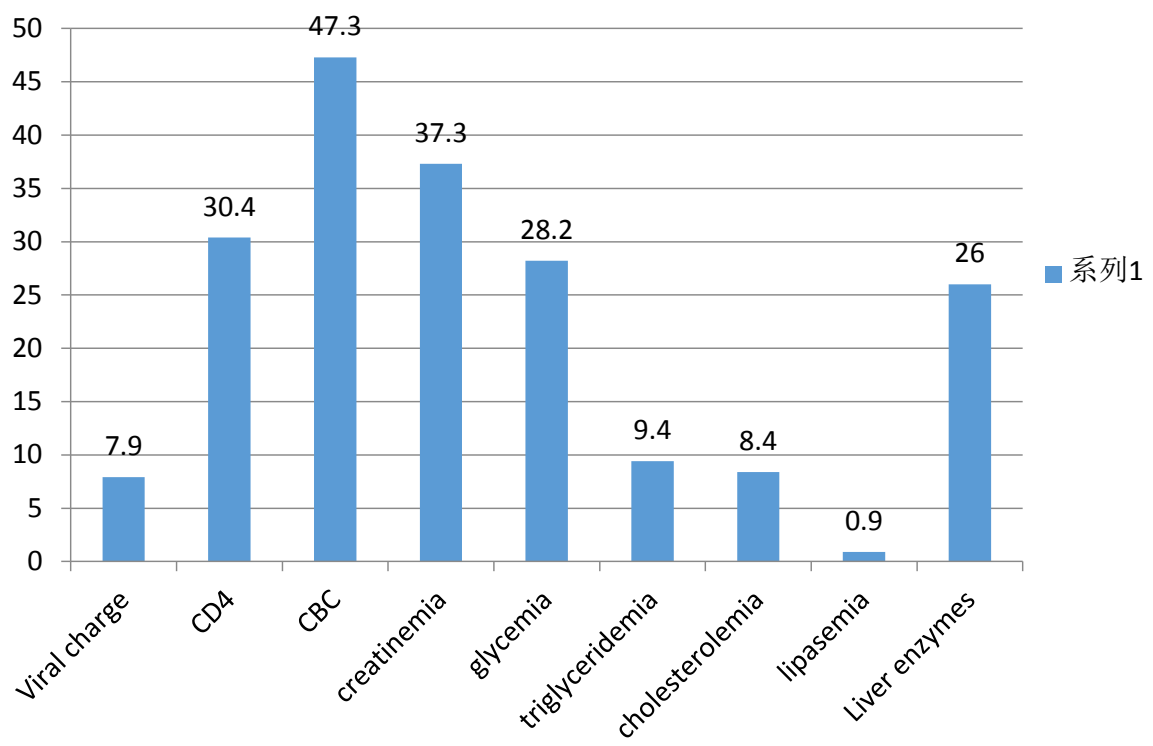

Figure 1. Pre-traitment assessment. CBC: Cell Blood Count; CD4: CD4 lymphocytes. 


\section{The organization of structures}

All health centres have a consultation room, a drugstore, and a laboratory. Only general hospital have a radiology service.

In 9 centres out 13, consultation rooms were not equipped with nor a computer nor an information and education material for patients (TV set, video, information flyers, information notice, a wooden penis, condom, etc.). Only the two drugstores of ATC have the fundamental living equipment (shelves, refrigerator, room thermometer, dustbin, air conditioner or effective air). Here are the characteristics of the drugstores in the other care centres: insufficient space to stock drugs, bad air conditioning in the room in three cases (23.1\%), a bad electricity provision in three cases $(23.1 \%)$, drugs in a disorder state in four cases (30.8\%), recurrent ARD stock shortage in eleven cases (84.6\%). The basic laboratory equipment (refrigerator, centrifugal, micropipette, incubator, ELISA reader, reagent, etc.) was found in eleven centres out of thirteen. There was not an automatic door in all laboratories, nor a room dedicated to infectious material, stink with foot, knee, elbow control, and no aspirated air conditioning condition. None of the thirteen centres has a waste incineration.

\subsection{Staff Organization}

Table 2 provides information regarding staff organization in sanitary offices.

$\left.{ }^{*}\right)$ The medical team is composed of seventeen doctors among whom six pediatricians. Fourteen doctors (82.3\%) have had no training on how to care about people living with HIV. Three centres out of thirteen have a pharmacy supervisor who is a pharmacist. The other supervisors were either doctors or nurses. In general, none of the supervisors have been trained in taking care of children living with HIV. Laboratory supervision was taken in charge by qualified technicians and there were only data managers at two ATC.

\subsection{Data Management}

Data concerning patients were recorded in medical files in twelve centres out off thirteen. In one centre, notebooks were taken as a support to collect data. Synthesis tables about cyclical clinical and biological follow up that are available at the CTA were filled by twenty-nine patients (16.3\%) out off one hundred and seventy eight. Medical files are kept on shelves at twelve centres, in cartons under the ground in one centre. Computerized data base was only found at ATC.

Table 2. Personnel distribution at sanitary office.

\begin{tabular}{|c|c|c|c|c|c|c|}
\hline Centres & Doctors & $\begin{array}{l}\text { Pharmacy } \\
\text { supervisor }\end{array}$ & $\begin{array}{l}\text { Laboratory } \\
\text { supervisor }\end{array}$ & Psychologist & $\begin{array}{c}\text { Social } \\
\text { assistant }\end{array}$ & $\begin{array}{c}\text { Data } \\
\text { manager }\end{array}$ \\
\hline CTA & 3 & 0 & 2 & 2 & 2 & 2 \\
\hline $\mathrm{CHU}$ & 4 & 1 & 1 & 1 & 1 & 0 \\
\hline General hospitals & 3 & 3 & 3 & 1 & 2 & 0 \\
\hline Base hospital & 7 & 6 & 7 & 1 & 1 & 0 \\
\hline Total & 17 & 10 & 13 & 5 & 6 & 2 \\
\hline
\end{tabular}




\subsection{Comments}

This study aimed at improving the care of children living with HIV in Congo had the advantage of being carried out in almost all the departments. However, the non-random selection of the framework and the absence at national level of a normative framework setting the package of activities per center, the number and quality of healthcare providers are undoubtedly the limits of it.

It follows from this study that pediatric care of people living with HIV (PLHIV) is not done in two out of eleven departments. The entire package of activities for their care is available only in the two CTAs, which also have units entirely dedicated to the care of PLHIV. It is also worth noting that the dispensation of ARDs in Congo is not based on any standard. Working conditions in laboratories do not guarantee the safety of providers, and no care center has all the minimum staff required by international standards. The data management of PLHIV is still empirical.

\subsection{Offer of Cares and Availability of Packages of Activities.}

In the Congo, the management of pediatric HIV/AIDS is not effective throughout the country. Thus, two departments are not covered. However, the 2009 seroprevalence survey shows a high prevalence of HIV/AIDS in these departments: 1.5 and 3.9 respectively [4].

In both Congo and Cameroon [5], HIV ATC are the only ones offering the entire package of activities as established by WHO. Other health facilities are limited to purely somatic management, whereas adherence and compliance with treatment also depend on the quality of psychological and socio-environmental care [6]. The same observation was made by ZONGO in Benin. The importance of psychosocial care justifies why in Benin it has been of great interest to the voluntary sector [7].

Serology is the main diagnostic method ( $90.3 \%$ in this work), which is done in coherence with the national AIDS council (CNLS) screening algorithm [8]. However, clinical and biological monitoring data available only in $74.6 \%$ of cases, is a major handicap for children living with HIV. This follow-up deficit is the corollary among others, of the recurring rupture of reagents and medications and the lack of professionalism of care providers.

The delay in diagnosis of HIV infection is common in Africa, as already reported in Sierra Leone, Côte d'Ivoire and Senegal [9] [10] [11]. In this study $83.3 \%$ of children were diagnosed in stage 3 of the WHO. Yet, children diagnosed have the same rate of medical visits as in France and Niger in accordance with WHO recommendations [8] [12]. Capacity-building for national HIV/AIDS programs through the intensification of awareness-raising and screening campaigns stand undoubtedly as the primary prevention.

\subsection{Organization of Structures and Staff}

In the Congo, the organization of treatment for the care of PLHIV is very dis- 
proportionate, as these are only possible in the ATCs located exclusively in the two major cities namely Brazzaville and Pointe-Noire. Other health facilities, on the other hand, use the common rooms that do not have the necessary equipment for the IEC of patients as recommended by the Rwandan and Haitian health authorities in collaboration with the WHO [13] [14].

Other factors that impede the organization of care include, among others, the provision of antiretroviral drugs that do not comply with the International Pharmaceutical Federation (FIP) standards: adequate and well-ventilated storage space; Route of administration, on shelves, in a secure cabinet or in refrigerators as required, as well as a constant power supply [15]. The recurrent ruptures of ARD stocks in $84.6 \%$ of pharmacies also contribute negatively to the care of children living with HIV.

The working environment in the laboratories of HIV care centers guarantees the safety of services and the external environment [16]. In the Congo, in this study these conditions are not guaranteed. Similarly, the lack of a radiology service in many treatment centers does not guarantee an efficient management of PLHIV whose association with opportunistic respiratory diseases is known.

One of the essential components of pediatric care for PLHIV is the quality of the staff dedicated to the task. Thus, under the minimum conditions, each center must have: a physician, a psychologist, a social worker, laboratory and pharmacy agents, a data manager [17]; this is not the case in Congo.

The lack of specific training for children living with HIV for almost all providers and the tiny number of pediatricians in care teams raises the issue of the quality and relevance of the information transcribed.

\subsection{Data Management}

The storage of data on physical media without recourse to the computer tool, as noted in the pediatric care centers of PLHIV, constitutes an obstacle to the multidimensional analysis of the monitoring variables. Another important factor is the quality of the transcription of information on the available media. Almost all of the variables are reported inconsistently as in KOUASSI in the Ivory Coast [10].

\section{Conclusion}

It follows from this work on the evaluation of pediatric care of HIV/AIDS that it is not yet optimal. It is characterized by the qualitative and quantitative inadequacy of the services offered and the staff, the poor quality of the infrastructures and the empirical management of the data.

\section{References}

[1] UNAIDS: Global Report 2013. http://www.unaids.org/

[2] UNAIDS: AIDS by the Numbers 2015. http://www.unaids.org/

[3] Ministère de la Santé, République du Congo. Rapport PNLS 2014. 
[4] CNLS (2009) Enquête de séroprévalence et sur les indicateurs du SIDA au Congo. Brazzaville, $193 \mathrm{p}$.

[5] FISSOU G (2013) Evaluation de l'offre des services des centres de traitement agrées pour le VIH/SIDA de la ville de Yaoundé. Thèse de médecine n 2938. Yaoundé, Cameroun.

[6] OMS (2013) Lignes directrices unifiées sur l'utilisation des antirétroviraux pour le traitement et la prévention de l'infection à VIH-Recommandations pour une approche de santé publique. Genève, $272 \mathrm{p}$.

[7] Zongo, M., Capochichi, J., Gandaho, P., et al. (2009) Prise en charge psychosociale des personnes vivant avec le VIH au Bénin. Santé publique, 21, 631-639.

[8] 38-CNLS (2010) Manuel de Prise en Charge pédiatrique de l'infection à VIH. Brazzaville, $89 \mathrm{p}$.

[9] Hounmenou, K., Lamontagne, F., D’Ortenzlo, E., et al. (2014) Evaluation des pratiques de dispensation et des effets produits sur les connaissances des patients, sur l'observance aux traitements et sur l'expérience des soins reçus: Résultats dans 2 hôpitaux de Freetown en Sierra Leone. In: AFRAVIH 2014. $7^{\text {ème }}$ Conference francophone VIH/Hépatites, avril 2014, Montpellier, France. Niamey: SOLTHIS, 2014. Disponible sur: http://www.solthis.org/ (consulté le 15.08.2014).

[10] Kouassi Kan, V., Coly, A., N’Guessan, J., et al. (2014) Facteurs influençant la sortie des Patients vivant avec le VIH du circuit de traitement en Côte-d'Ivoire. Rapport University Research Company, Abidjan, 42 p.

[11] Diack Mbaye, A., Signaté Sy, H., Diagne, N.R., et al. (2004) Aspects épidémiologiques et cliniques de l'infection à VIH de l'enfant au centre hospitalier national d'enfants Albert-Royer à Dakar. Archives de pédiatrie, 12, 404-409.

[12] Jacomet, C., Cormerais, L., Peyrol, F., et al. (2014) Parcours de soins des personnes vivant avec le VIH et suivies à l'hôpital en 2012. Bulletin Epidémiologique Hebdomadaire, 24-25, 422-428.

[13] Moussa, S., Yahannon, N., Diallo, L., et al. (2014) Rétention après l'initiation au traitement antirétroviral des personnes vivant avec le VIH au Niger: Une analyse de survie de la base de données nationale. 7 th Conference francophone VIH/ Hépatites, Montpellier. http://www.solthis.org

[14] Port-au-Prince (2008) Ministère haïtien de la santé publique et de la population. Manuel de normes de prise en charge clinique et thérapeutique des adultes et adolescents vivant avec le VIH. 102 p.

[15] Ministère rwandais de la santé (2007) Guide de prise en charge des personnes infectées par le VIH. Kigali, 185 p.

[16] Fédération Internationale Pharmaceutique (2008) Recommandations pour la gestion d'une pharmacie et la dispensation de médicaments antirétroviraux dans les pays à ressources limitées. La Haye, $86 \mathrm{p}$.

[17] World Health Organization (WHO) (2004) Laboratory Biosafety Manuel. Third Edition, Geneva. 
Submit or recommend next manuscript to SCIRP and we will provide best service for you:

Accepting pre-submission inquiries through Email, Facebook, LinkedIn, Twitter, etc. A wide selection of journals (inclusive of 9 subjects, more than 200 journals)

Providing 24-hour high-quality service

User-friendly online submission system

Fair and swift peer-review system

Efficient typesetting and proofreading procedure

Display of the result of downloads and visits, as well as the number of cited articles Maximum dissemination of your research work

Submit your manuscript at: http://papersubmission.scirp.org/

Or contact ojped@scirp.org 